УДК 930 [339.9.394] : 39 (100)

DOI: https://doi.org/10.33782/eminak2020.2(30).430

\title{
ГЛОБАЛЬНИЙ КАПІТАЛІЗМ VS ТРАДИЦІЙНА КУЛЬТУРА: ГРОШІ У ДИСКУРСІ ЗАРУБІЖНОЇ КУЛЬТУРНОЇ АНТРОПОЛОГІЇ*
}

\author{
Тетяна Тхоржевська ${ }^{1}$, Юлія Богуславська ${ }^{2}$ \\ Одеський національний політехнічний університет (м. Одеса, Україна) \\ 1 e-mail: tvtchor@gmail.com; ORCID: https://orcid.org/0000-0002-4696-4636 \\ 2 e-mail: boguslav.yulia@gmail.com; ORCID: https://orcid.org/0000-0003-1360-9379
}

У статті подано огляд теорій зарубіжних антропологів щодо місця праці та грошей у трансформаційних суспільних процесах. Простежено переважання уявлень про гроші як руйнівну силу, що нищить традиційні культури та ринкові відносини, які повністю змінюють ставлення до праці та грошей, підміняючи моральні норми утилітарною користю. Зазначено наявність альтернативних точок зору на мотивацію праці та можливість мирного співіснування глобального та традиційного у ставленні до грошей. Підкреслюється, що у сучасних дослідженнях співіснують обидва підходи.

Ключові слова: економічна антропологія, антропологія грошей, традиційна культура, мотивація праці, зіткнення культур

Проблема співвідношення глобального та національного (локального) є сьогодні одною з пріоритетних у дослідженнях з культурної/соціальної антропології; «ця дихотомія має тенденцію представляти глобалізацію, зокрема працю, капітал та комунікацію, як таку, що нейтралізує важливість місця»1. Саме антропологічний підхід, грунтований на польових дослідженнях, дозволяє вивчати, в який спосіб глобальні явища позначаються на житті окремої локальної спільноти. Важливим напрямом культурної антропології є економічна антропологія, яка впродовж XX-XXI ст. досліджує, у тому числі, зіткнення «глобального капіталізму» і «традиційної культури». Одним з символів ринкової економіки, яка усвідомлюється як прояв глобальності, $€$ гроші. Отже, саме уявлення про гроші є одним з маркерів того, у який спосіб «традиційна культура» зустрічає «глобальний капіталізм».

Пропонована стаття є історіографічною, й отже, їі джерельною базою є праці зарубіжних культурних антропологів у галузі означеної проблематики. Ми користувалися як англомовними текстами, так і тими, що $є$ у російському перекладі. Текстів з цієї тематики в українському перекладі нам знайти не вдалося. Звісно, ми свідомі того, що оглянути весь загал робіт такого плану неможливо, тому вибірковість тут неминуча.

Здійснювати вибір наукових розвідок нам допомогли роботи, присвячені огляду літератури в галузі економічної антропології або безпосередньо антропології грошей. Крім того, дослідники зазвичай на початку власних робіт аналізують попередні досягнення, що також стало у пригоді. Так Кейт Харт (Keith Hart), один з найвідоміших дослідників у галузі економічної антропології, зауважив, що «антропологи не люблять грошей», що виходить з солідарності антропологічного цеху з «незамож-

\footnotetext{
${ }^{*}$ Статтю підготовлено у ході роботи над проектом, що виконується за фінансової підтримки Канадського інституту українських студій.

${ }^{1}$ Holston J., Appadurai A. Cities and Citizenship // Public Culture. 1996. № 8. P. 190. URL: http://www.arjunappadurai.org/articles/Appadurai_Cities_and_Citizenship.pdf
} 
ними проти нищення культурної різноманітності внаслідок глобалізації»; він також називає теорію Марселя Мосса «найвищою точкою обговорення грошей антропологами» й підкреслює, що антропологи вивчають сприйняття грошей іншими суспільствами, але не своїм². Американський антрополог Уильям M.Maypep (William M. Maurer) згадує класичні для субдисципліни праці Зіммеля, Мосса, Поланьї, Бохананна, Таусіга, яким антропологи «зберігають вірність», Пері й Блоха, які, всупереч заведеної практики, заперечували руйнівну силу грошей. Він зауважує, що коло проблем, які досліджує антропологія грошей, зазнало не так багато змін, хоча їх потребує; зокрема, антропологи продовжують сперечатися «про взаємозв'язок між «реальною» економічною вартістю та «несуттєвими» фікціями необов'язкових валют і фінансів», вивчати наслідки переходу від «справжніх» грошей до вексельних, перейматися «нав'язуванням капіталістичних валют колоніальним шляхом»3. Хайко Шрадер виділяє розуміння антропологами стадій виникнення грошей, теорій походження грошей, їхніх функцій. Підсумовуючи огляд теорій, автор стверджує, що «наявний значний антропологічний розділ про примітивні гроші та форми обміну й економічний розділ про сучасні теорії грошей і політики», а найбільш важливим, на його думку, є дослідження «грошей, їх використання та довіри»4.

Метою пропонованої статті $\epsilon$ аналіз дискурсу уявлень про гроші як маркер ринкової економіки у зарубіжній культурній антропології. Конкретизуючи мету зазначимо, що завдання, які ми ставимо в цій роботі, полягають у тому, щоб по-перше, з'ясувати, в який спосіб дослідники осмислюють зіткнення «глобального капіталізму» і «традиційної культури»; по-друге - яке місце у цьому осмисленні займають гроші, праця та мотивація праці.

Розгляд варто почати з Броніслава Малиновського, якого справедливо вважають одним з фундаторів економічної антропології. Він досліджував, зокрема, феномен кула у папуасів Тробріанських островів. Перше, що варто відзначити - Малиновський заперечує в людській праці можливість суто економічних мотивів. Він каже, що тробріанець «працює, маючи для цього складні мотиви, які вкорінені у соціальну та традиційну природу, й прагне до тої мети, яка не конче спрямована на задоволення миттєвих бажань або утилітарної користі»5.

Малиновський звертає увагу на те, що робота виконується не за принципом найменшого зусилля, навпаки, багато часу та енергії спрямовані на дії, що не містять жодної утилітарної необхідності. Він вважає, що праця не є лише засобом досягнення мети, вона сама певною міроює метою. Кількістю роботи тробріанець вимірює престиж. Велика площа добре обробленого городу дає можливість отримати титул токвайбагула (добрий землероб), який є підставою для гордості. Усі результати праці (урожай) викладаються на ділянках та усі мешканці селища уважно їх оглядають й вихваляють кращі.

\footnotetext{
2 Hart K. Notes towards an anthropology of money // Kriticos an international and interdisciplinary journal of postmodern cultural sound, text and image. 2005. Vol.2. URL: https://intertheory.org/hart.htm

3 Maurer B. Notes towards an anthropology of money // The Annual Review of Anthropologyisonline. 2006. Vol.35. P. 29. URL: https://www.annualreviews.org/doi/pdf/10.1146/ annurev.anthro.35.081705.123127

4 Шрадер X. Экономическая антропология. Санкт-Петербург: «Петербургское Востоковедение», 1999. C. 49. URL: http://anthro-economicus.narod.ru/files/Shrader_EA.pdf

5 Малиновский Б. Избранное: Аргонавты западной части Тихого океана / Пер. с англ. Москва: РОССПЭН, 2004. С. 78.
} 
Найважливішим, з погляду Броніслава Малиновського, доказом відсутності суто утилітарних мотивів праці $\epsilon$ те, що «всі надлишки, які він може отримати завдяки додатковим зусиллям, належатимуть не йому, а родичам його дружини»6.

Загалом стимулом до роботи у тробріанців $€$ не утилітарна користь (яка могла би бути означена у тому числі й категорією «гроші»), а слава й престиж. Малиновський каже, що тробріанцем, який працює, «керує не бажання задовольнити власні потреби, але складне поєднання вимог традиції, боргу та обов'язків, віри у магічну силу, а також суспільних прагнень і честолюбних сподівань»7.

Отже, Малиновський не позначає працю тробріанців як жертвування. Це важливо підкреслити, оскільки Зіммель у відомій праці, присвяченій філософії грошей, артикулює розуміння праці саме як жертви: «Оскільки є бажання... уникнути обтяжливих зусиль, будь-яка робота... $є$ жертвуванням...». Разом з тим філософ не заперечує, що існує ще «деяка кількість прихованої енергії праці... вона виявляється завдяки прагненню до добровільної праці, яка не обумовлена ані потребами, ані етичними мотивами» 8 , чому відповідають висновки Малиновського.

Польові дослідження Б. Малиовського стали у пригоді багатьом дослідникам. Так, на них спирався Марсель Мосс, вивчаючи «економіку дару», яка діяла, створюючи ринкові відносини у не-ринкових, або до-ринкових суспільствах9.

На польові дослідження та висновки Броніслава Малиновського спирався також один з найвідоміших теоретиків у галузі економічної антропології Карл Поланьї, який значну увагу приділяє як грошам, так і праці. Він стверджує, що гроші $\epsilon$ грошима тоді, коли вони використовуються або для оплати, або як міра вартості, або як засіб обміну10.

К. Поланьї аналізує домодерні суспільства і стверджує, що «у Стародавньому світі гроші мали цільовий характер [special-purpose money]. Для виконання ними різних ролей використовувалися різні об'єкти; більш того, кожен спосіб використання грошей був інституціонально оформлений незалежно від іншого. Це призвело до найсерйозніших наслідків. Наприклад, немає ніякого протиріччя в тому, щоб для здійснення «платежу» використовувати засіб, за допомогою якого не можна нічого купити; або ж у тому, щоб в якості «стандарту» служили об'єкти, які не використовуються як засіб обміну» 11 . Продовжуючи цю думку, яка певною мірою перетинається з розуміннням первісних грошей Моссом, Поланьї виокремлює багатофукціональні гроші та гроші спеціального призначення ${ }^{12}$. Він вважає, що «сучасні гроші, на противагу примітивним, демонструють яскраву схожість як з мовою, так і з писемністю. Всі вони мають єдину граматику. Всі три знакові системи організовані відпові-

\footnotetext{
${ }^{6}$ Ibid. C. 79.

7 Ibidem.

8 Зиммель Г.

Философия

денег.

1978.

C. 28.

URL:

www.srinest.com/book_897_chapter_13_Georg_Zimmel_FILOSOFIJA_DENEG.html

9 Мосс М. Очерк о даре. Форма и основание обмена в архаических обществах // Мосс М. Общества. Обмен. Личность. Москва: «Восточная литература» PAH, 1996. С.1-2. URL: http://anthroeconomicus.narod.ru/files/Moss_Present.pdf

10 Поланьи К. Экономика как институционально оформленный процесс // «Великая трансформация» Карла Поланьи: прошлое, настоящее, будущее. Москва: ГУ-ВШЭ, 2007. С. 66. http://rustemnureev.ru/wp-content/uploads/2011/01/277.pdf

11 Ibid. C. 67.

12 Поланьи К. Семантика использования денег // «Великая трансформация» Карла Поланьи: прошлое, настоящее, будущее. Москва: ГУ-ВШЭ, 2007. С. 127. http://rustem-nureev.ru/wpcontent/uploads/2011/01/277.pdf
} 
дно до складного зводу правил використання символів, причому загальні правила поширюються на всі ці символи»13. Тобто «сучасні гроші» $\epsilon$ грошима багатофункціональними, грошима універсального призначення; водночас можуть бути використані для оплати, як міра вартості, як засіб обміну.

Архаїчні ж суспільства, на думку Поланьї, не знали грошей універсального призначення: «Архаїчне суспільство не знало грошей, придатних для «всіх цілей». Тут різні предмети можуть бути по-різному використані в якості грошей. Отже, не існує такої «граматики», якій повинні були б підкорятися всі способи використання грошей. Жоден вид предметів не «заслуговує» називатися грошима, скоріше, термін відноситься до невеликої групи предметів, кожен з яких міг би служити в якості грошей, але тільки одним - своїм особливим чином»14. Отже, йдеться про гроші «спеціального призначення», які могли мати одну з функцій сучасних грошей.

Важливим $є$ виокремлення К. Поланьї також використання грошей для накопичування багатства. «Підгрунтям використання грошей як засобу накопичення багатства $є$ необхідність здійснювати платежі» 15 .

Поланьї також зазначає, що «зберігання багатства в якості інституту примітивної економіки починається зі збору та зберігання продуктів першої необхідності;... зберігання продуктів (предметів) першої необхідності $є$ накопиченням продуктів як засобів існування, які зазвичай використовуються потім як засіб для здійснення платежу» 16.

Щодо праці, Карл Поланьї спочатку аналізує мотивацію праці у «первісних економіках», спираючись знову таки переважно на праці Малиновського. Він каже, що в цих економіках «...виробнича або економічна система організована у такий спосіб, що участь у виробництві ні для кого не є результатом страху перед голодом. Незалежно від того, бере людина участь або ні у виробничих процесах співтовариства, вона завжди має свою частку в спільних ресурсах їжі» ${ }^{17}$. Далі Поланьї зазначає спадковість між «примітивним суспільством» та «цивілізованими типами суспільств», під якими він розуміє «античне деспотичне суспільство, феодальне суспільство, місто-державу, середньовічне міське суспільство, меркантілістське суспільство або регуляційну систему, що існувала у XVIII столітті у Західній Європі»18. Він каже, що економічна система в усіх цих суспільствах існує в межах соціальної системи, а мотиви праці пов'язані з «громадським звичаєм або традицією, дотриманням релігійних настанов, політичною вірністю юридичними обов'язками або адміністративним регулюванням»19. Отже, підсумовує Поланьї, «не голод, не виграш, а гордість й престиж, ранг і статус, публічна шана або особиста репутація забезпечували стимули для індивідуальної участі у виробництві»20.

Зовсім інакше Поланьї характеризує ринковий капіталізм, який, на його думку, поміняв місцями «статус» і «контракт». Це відбувалося внаслідок великої трансфор-

\footnotetext{
13 Ibidem.

14 Ibidem.

15 Ibid. C. 132.

16 Ibid. C. 134.

17 Поланьи К. О вере в экономический детерминизм // «Великая трансформация» Карла Поланьи: прошлое, настоящее, будущее. Москва: ГУ-ВШЭ, 2007. С. 25. URL: http://rustem-nureev.ru/wpcontent/uploads/2011/01/277.pdf

18 Ibid. C. 26.

${ }^{19}$ Ibidem.

20 Ibidem.
} 
мації, яка призвела до того, що маргінальні до XIX ст. ринкові відносини почали визначати економіку, а стимулами до праці стали або страх голоду (переважно для тих, хто продає працю за гроші), або бажання виграшу (для тих, хто має капітал) ${ }^{21 .}$

Руйнівність ринкової економіки та інші аспекти теорії Поланьї стали підгрунтям для багатьох антропологів, які вивчали ті або інші аспекти економічної діяльності традиційних суспільств у другій половині XX - на початку XXI ст. й не втратили актуальності до сьогодні. Спираючись на його концепцію у другій половині XX ст. було проведено значну кількість антропологічних досліджень, зокрема присвячених економічному розвитку колоніальних та постколоніальних країн. Найвідомішим серед них є праця Пола Боханнана (Paul Bohannan), присвячена функціонуванню грошей у культурі народу Тів 22.

Боханнан розглянув на прикладі «обмінного шлюбу» побутування грошей «спеціального (або окремого) призначення». До контактів з європейцями, - стверджує Боханнан, - у народу Тів існувала багатоцентрична економіка, тобто «економіка, в якій всі товари, що підлягають обміну, потрапляють у дві або більше взаємовиключних сфер, кожна з яких обмежена різними інститутами та різними моральними цінностями». Наприклад, до одної з сфер належали овочі, крупи, курки; до другої велика рогата худоба, раби, медицина, магія. Обмінний шлюб належав, за Бохананном, до «престижної сфери».

У своїй праці Боханнан також приділяє увагу тому, як саме вплинули на життєдіяльність Тів контакти з європейцями, внаслідок яких були впроваджені гроші загального призначення. Боханнан стверджує, що наслідком було знищення багатоцентричної економіки, коли різні товари мали різні сфери, де вони оберталися й не перетиналися між собою. Хоча металеві прути грали значну роль у престижній сфері, ціннісна система Тів була грунтована на тому, що латунні прути або крупна рогата худоба не є еквівалентом жінки. Еквівалентом жінки могла бути лише інша жінка. Впровадження універсальних грошей підважило цей принцип: «Тів висловлюють занепокоєння з приводу того, що від них вимагають «продати» своїх дочок і «придбати» дружин»23. Отже, глобальний капіталізм осмислюється як руйнівний для народу Тів.

Майкл Таусіг (Michael T. Taussig) у своїй класичній праці 1980 р. подає приклади того, у який спосіб відбувається взаємодія ринкової економіки з традиційним суспільством; у фокусі його аналізу перебувають саме гроші та пов'язані з ними уявлення. Зазначимо, що Таусіг, критикуючи руйнівну силу ринкової економіки, говорить про те, наскільки важко було капіталу знайти робочу силу серед місцевого населення, що реакцією місцевого люду, який під примусом йшов працювати, була байдужість до грошової винагороди та тої раціональності, яка $\epsilon$ спонукальною для hото economicus ${ }^{24}$.

В антропологічних оглядах, пов'язаних з вивченням грошей, заведено вважати, що вперше тезу про руйнівну силу грошей під сумнів поставили Дж. Перрі (J. Parry)

\footnotetext{
21 Ibid. C. 26-29.

22 Bohannan P. The Impact of Money on an African Subsistence Economy Source // The Journal of Economic History. 1959. № 19.4. P. 491-503.

23 Ibid. P. 503.

24 Taussig M. The Devil and Commodity Fetishism in South America. The University of North Carolina Press. 2010. P. 41-45. URL: https://selforganizedseminar.files.wordpress.com/2011/07/taussig_devil_commodity.pdf
} 
та (М. Блох) M. Bloch²5. Проте варто зазначити, що раніше візію мирного співіснування глобального 3 традиційним запропонувала Елізабет Хіршман (Elizabeth C. Hirschman) у статті «Примітивні аспекти споживання у сучасному американському суспільстві»26. Розглядаючи споживчу поведінку у США на прикладі 4-х кейсів (темношкірі, італійці, англопротестанти, євреї), вона зауважує, що елементи етнічного або традиційного існують в межах економіки США: «На відміну від переважаючого погляду на американського споживача, як сучасного індивіда, я пропоную діалектичну і, ймовірно, суперечливу позицію. Я вважаю, що різноманітні архаїчні процеси, практики та настанови, які мають істотний вплив на поведінку та переконання споживачів, вбудовані в сучасне американське суспільство. Я припускаю, що традиція предків визначає багато актів споживання, що ідентичність етнічної групи може домінувати над особистими уподобаннями в кількох контекстах споживання. Означені архаїзми у сучасному суспільстві не $є$ аномаліями, вони є важливими та тривалими аспектами життєдіяльності нашого суспільства» ${ }^{27}$.

Дж. Перрі та М. Блох стверджували, що вся наша культурна традиція усвідомлює впровадження грошей як «неймовірно потужного агента глибоких соціальних і культурних перетворень», у тому числі у зв'язку з тим, що «руйнуючи громаду, гроші деперсонізують суспільні відносини» ${ }^{28}$. Причому таке усвідомлення грошей існує незалежно від того, оцінюють дослідники цей процес позитивно чи негативно.

Автори кажуть про відсутність «будь-якого простого розмежування між типом містичної аури, що оточує об’єкти обміну в капіталістичній і докапіталістичної економіках»; і впевнені у тому, що розуміння грошей як революційної сили, що «неминуче підриває моральну економіку традиційних суспільств... стало некритичним для антропологів»29. Для прикладу Пері й Блох аналізують наведену вище роботу Пола Боханнана і зауважують, що несприйняття втручання грошей у «престижну сферу», тобто сферу обміну жінок, було характерно для старійшин, які тримали цей процесс під власним контролем. Разом з тим, Пері й Блох кажуть, що нема жодних доказів того, що впровадження грошей засуджувалося молодими людьми. Окрім того, вони стверджують, що перехід між різними сферами, а, отже, й побутування грошових функцій можна знайти в економіці Тів до контактів з європейцями.

Далі автори наводять декілька прикладів з різних етнографічних матеріалів, яі демонструють інкорпорацію грошей у ритуальні практики й ціннісні системи традиційних суспільств, а те, що Боханнан визначав як сфери з різною мірою «престижності», Пері й Блох відносять до короткого та довгого обмінного циклів ${ }^{30}$.

Загальний їх висновок полягає у тому, що гроші існують у межах культурної матриці, і тому вони не здатні їі зруйнувати.

Цікавий підхід демонструє Хайко Шрадер. Передусім він характеризує ставлення до праці, накопичення й капіталу у так званих «замкнених спільнотах», стверджуючи, що там «отримання прибутку підлягає соціальному засудженню, а сам прибуток підлягає перерозподілу», побутують уявлення про працю як про фізичну роботу, а

\footnotetext{
25 Parry J., Bloch M. Money and the morality of exchange. Cambridge University Press, 1989. 284 p.

${ }^{26}$ Hirschman E. Primitive Aspects of Consumption in Modern American Society // Journal of Consumer Research, 1985. Vol. 12. No. 2. P. 142-154.

27 Ibid. P. 143.

28 Parry J., Bloch M. Op. cit. P. 5.

29 Ibid. P. 9.

30 Ibid. P. 16.
} 
про торговців та банкірів - що вони не працюють, а «роблять гроші поки сплять»31. Шрадер підкреслює, що те саме можна зауважити про середньовічну Європу.

Не заперечуючи руйнівного впливу ринку та грошей на «замкнені спільноти», він зауважує, що «модернізація - це шлях від традиції до сучасності, від домодерного суспільства до суспільства ринкового. Цей процес не завжди відбувається безперешкодно. Він потребує руйнації минулої соціальної структури, «розчарування» світу, секуляризації та раціоналізації життя»32. Важливу роль у цьому процесі відіграють грошові символи та еволюція довіри до них у суспільстві. Так, недовіра до грошей за часів середньовіччя полягала у тому, що гроші повинні були обов'язково мати еквівалент (переважно золото). Згодом подібна недовіра була замінена довірою. Довіра - це очікувана поведінка, довіра до системи грошового обміну. Внаслідок довіри до системи, людина впевнена, що отримавши гроші за певний товар, вона зможе скористатися ними для купівлі іншого товару.

Шрадер, таким чином, говорить про ту саму руйнацію культурної моделі у замкнених спільнотах, яку зауважує, наприклад, Боханнан та інші дослідники традиційних культур. Така руйнація відбувається, у тому числі, за рахунок еволюції довіри до грошових символів. Разом з тим він зауважує, що такі самі процеси характерні для європейського середньовіччя. Фактично, Х. Шрадер говорить про ті самі процеси, але на великому часовому відрізку й у контексті «західної культурної моделі».

Починаючи з 1990-х років у зв'язку з руйнацією економічної системи соціалізму, антропологи звернули увагу на постсоціалістичні трансформації, зокрема вплив ринкової економіки на зміну уявлень про гроші та працю. Варто підкреслити, що теорія Поланьї стала підгрунтям для багатьох подібних досліджень.

«Моя мета, - зазначає Кріс Хан, - розглянути постсоціалістичі перетворення після 1989 року у контексті аналізу драматичного впливу утопії саморегульованого ринку у попередньому столітті, який здійснив Поланьї». Хан вважає, що крах соціалізму призвів до руйнації «морального порядку» у тому сенсі, що «більшість людей вважає самоочевидним те розуміння світу, у якому вони жили», ілюструючи це прикладом трансформації поглядів сільськогосподарських працівників 33 . В іншій роботі Хан вивчає «моральне розорення» та важке сприйняття впровадження ринкових відносин на прикладі Китаю, Росії, Болгарії, Угорщини ${ }^{34}$.

Керолайн Хамфрі, аналізуючи пострадянські трансформації, наголошує на важливості колективів для радянських людей і на тому, що руйнація колективів у сільському господарстві на початку 1990-х років призвела до «зсунення радянської ієрархії соціальних осередків до великої кількості «розсіяних» мереж, де гонитва за прибутком перевищує будь-які стосунки» ${ }^{35}$. Аналогічна ситуація простежувалася й у містах; важливе спостереження авторки стосується сприйняття пересічними людьми ринкових змін - свої власні негаразди й погіршення матеріального становища вони вважали наслідком «не економічного розрахунку, а чиєїсь особистої ворожосTi» 36 .

\footnotetext{
31 Шрадер Х. Экономическая антропология. Санкт-Петербург: «Петербургское Востоковедение», 1999. C. 100.

32 Ibid. C. 148.

${ }^{33}$ Hann K. Moral Dispossession // Inter Disciplines. 2011. № 2. P. 11-37.

${ }^{34}$ Ханн К. Отношения собственности в постсоциалистических обществах // Журнал исследований социальной политики. № 5. 2. С. 151-178.

35 Хамфри К. Постсоветские трансформации в азиатской части России (антрополог. очерки). Москва: Наталис, 2010. С. 97.

36 Ibid. C. 98.
} 
Вартий уваги проведений Хамфрі аналіз уявлень, присвячених вибуху торгової активності 1990-х років, власне «торговцям» та їхнім способам отримувати гроші. Уявлення про торгівлю Хамфрі аналізує з погляду звички до існування у межах колективів: «Моя ідея полягає в тому, що існування останніх [торговців] $є$ викликом лояльності, яка загострюється під час нової битви за виживання. Окрім того, що торговці не виправдовують свого існування продуктивною працею на тому чи іншому підприємстві; вони ще перетинають інституційні та просторові межі і роблять гроші на всіх тих аномаліях, з якими пострадянські люди змушені миритися. Їх діяльність йде врозріз з цінностями, які поділяються більшістю людей. В уявленнях людей вони забирають те, що по праву має належати вимушеним працювати без оплати «колективам» ${ }^{37}$.

Далі авторка зауважує, що вже наприкінці 1990-х років ставлення до торгівлі змінилося - більшість усвідомила, що торгівля дозволяє заробити гроші, а гроші - це шлях до свободи. Разом із тим Хамфрі підкреслює, що задоволення від користування грошима можна відчути лише у повністю монеторизованій економіці, а у Росії 1990x років справжніми грошима можна було назвати лише долари, які надавали повну свободу та відчиняли двері світового ринкуз8.

Концепт «моральна економіка» й надалі продовжує використовуватися антропологами для осмислення зіткнення глобального з традиційним. Так, Джейсон Хікель (Jason Hickel) у роботі «Ксенофобія» у Південній Африці: порядок, хаос та моральна економіка чаклунства» розповідає про скарги місцевих молодих чоловіків на те, що «іноземці крадуть нашу роботу» та акцентує увагу на тому, що цікавим є не сам факт впливу глобальної економіки на локальні спільноти й породжену ним кризу, а те, у який спосіб розуміють таку кризу представники локальної спільноти в контексті власних уявлень про моральну економіку та її протилежність ${ }^{39}$.

Глобальний капіталізм, ринкові відносини знову осмислюються як зло, у боротьбі з яким люди використовують різні стратегії. Так, Сара Мьюр (Sarah Muir) у роботі «Невдала валюта: гроші та критика середнього класу у посткризовому БуеносАйресі» аналізує сприйняття представниками аргентинського суспільства аргентинської валюти песо під час різкого падіння її курсу. Мешканці Аргентини, з якими співпрацює Мьюр, кажуть, що криза дозволила усвідомити абстрактну й вигадану природу грошей. Проте «усвідомлена вигаданість грошової вартості підсилила необхідність погодитися з їі фактичністю»40. Переконавшись, що гроші - то є фетиш, вони разом з тим готові й надалі грати в цю гру. Важливо, що усі поневіряння аргентинського середнього класу стосуються лише песо, але не долара: «Мої співрозмовники сприймали «провал» песо як провал конкретної форми грошей, а не як зразок провалу грошей в цілому. Вони наполягали на тому, що ринкові оцінки відображають реальні і неминучі відмінності між валютами тривалого користування (тобто доларом США) і їх фальшивими підробками (тобто аргентинським песо). Таким чином, обвал прив'язки підірвав довіру до песо, але не до долара, який продовжував в посткризовому середовищі середнього класу служити ідеальним типом грошової форми» ${ }^{41}$.

\footnotetext{
37 Ibid. C. 127.

38 Ibid. C. 135.

${ }^{39}$ Hickel J. «Xenophobia» in South Africa: Order, Chaos, and the Moral Economy of Witchcraft // Cultural Anthropology. 2014. № 1. P. 103-127. DOI: 10.14506/ca29.1.07

40 Muir S. The Currency of Failure: Money and Middle-Class Critique in Post-Crisis Buenos Aires // Cultural Antropology. 2015. Vol. 30. № 2. P. 328. DOI: 10.14506/ca30.2.10

41 Ibid. P. 329.
} 
Подібна довіра до долара, про яку згадує Мьюр на прикладі Аргентини й Хамфрі на прикладі Росії, може бути усвідомлена як збереження (або навіть створення) довіри до глобального капіталізму, який просто зазнає невдачі в конкретному місці. I тут долар виконує роль символу недосяжного ідеалу. Щоправда варто підкреслити, що у згаданих роботах мова йде про середній клас, переважно торговців.

Вивчаючи бідніші прошарки населення, антропологи розповідають про способи співжиття з ринковою економікою, які тяжіють до ізоляції в межах певних груп. Такі спільноти з середини попри бідність виглядають привабливішими, ніж «великий світ». Про це йдеться, наприклад, у роботі Кетлін М. Міллар (Kathleen M. Millar) «Сумнівний подарунок: неоплачувана праця та зруйноване життя у Ріо-де-Жанейро, Бразилія», що розповідає про сміттєзвалище та спільноту навколо нього, яку не можуть полишити ті, хто відчуває себе тут вдома ${ }^{42}$. Брюс 0’Нейл (Bruce O’Neill), описує низхідну соціальну мобільність та безхатченків у посткомуністичному Бухаресті; люди, що опинилися «на дні», звинувачують у цьому ринкові відносини, до яких вони не змогли адаптуватися. Гроші мають важливе значення у життєвих наративах безхатченків, адже саме через цю категорію відбувається усвідомлення себе «колись» і «зараз»43.

Підсумовуючи, можна стверджувати, що усвідомлення зіткнення глобального й традиційного більшістю антропологів трактується як руйнація, що виходить $з$ традиції, започаткованої Поланьї й розвиненої Бохананном. Робота Пері й Блоха, в якій гроші не виглядають як руйнівна сила й пропонується можливість «мирного співіснування», стала важливим історіографічним фактом у цьому напряму досліджень; разом з тим останні розвідки антропологів свідчать про переважання «лінії Поланьї», а, отже про усвідомлення грошей та ринкової економіки як руйнівної сили для традиційних суспільств (або, за Шрадером, «замкнених суспільств»). Важливо також підкреслити, що антропологи зазвичай вивчають певні локальні спільноти, а не культуру загалом. Тому їхній погляд суттєво залежить від того, на якому щаблі соціальної ієрархії перебуває їхнє «поле».

\section{REFERENCES}

Bohannan, P. (1959). The Impact of Money on an African Subsistence Economy Source. The Journal of Economic History. Vol. 19. Issue 4. P. 491-503.

Hann, K. (2007). Otnosheniia sobstvennosti v postsocialisticheskih obshchestvah [Property Relations in Post-Socialist Societies]. Zhurnal issledovanii socialnoi politiki, 5 (2), 151-178 [in Russian].

Hann, K. (2011). Moral Dispossession. Inter Disciplines, 2, 11-37.

Hart, K. (2005). Notes towards an anthropology of money. Kriticos an international and interdisciplinary journal of postmodern cultural sound, text and image. Vol. 2, June. Retrieved from https://intertheory.org/hart.htm

Hickel, J. (2014). «Xenophobia» in South Africa: Order, Chaos, and the Moral Economy of Witchcraft. Cultural Anthropology, 29.1,103-127. DOI: https://doi.org/10.14506/ca29.1.07

Hirschman, E. (1985). Primitive Aspects of Consumption in Modern American Society. Journal of Consumer Research, 12.2, 142-154.

Holston, J. \& Appadurai, A. (1996). Cities and Citizenship. Public Culture, 8, 187-204.

Humphrey, K. (2010). Postsovetskie transformatsii v aziatskoi chasti Rossii [Post-Soviet transformations in the Asian part of Russia]. Moskva [in Russian].

Malinovskii, B. (2004). Izbrannoe: Argonavty zapadnoi chasti Tikhogo okeana [The Selected: Argonauts of the Western Pacific]. Moskva [in Russian].

42 Millar K. The Precarious Present: Wageless Labor and Disrupted Life in Rio de Janeiro, Brazil // Cultural Antropology. 2014. Vol. 29. 1. P. 32-53.

43 O'Neill B. Cast Aside: Boredom, Downward Mobility, and Homelessness in Post-Communist Bucharest // Cultural Antropology. 2014. Vol. 29. 1. P. 8-31. 
Maurer, B. (2006). Notes towards an anthropology of money. The Annual Review of Anthropology, 35, 1536. DOI: 10.1146/annurev.anthro.35.081705.123127

Millar, K. (2014). The Precarious Present: Wageless Labor and Disrupted Life in Rio de Janeiro, Brazil. Cultural Antropology, 29. 1, P. 32-53. DOI: 10.14506/ca29.1.04

Moss, M. (1996). Ocherk o dare. Forma i osnovanie obmena v arkhaicheskikh obshchestvakh. [Essay on the Gift. The Form and Basis of Exchange in Archaic Societies]. Moss M. Obshchestva Obmen Lichnost. Moskva. Retrieved from http://anthro-economicus.narod.ru/files/Moss_Present.pdf [in Russian].

Muir, S. (2015). The Currency of Failure: Money and Middle-Class Critique in Post-Crisis Buenos Aires. Cultural Antropology, 30 (2), 311-335. DOI: 10.14506/ca30.2.10

O'Neill, B. (2014). Cast Aside: Boredom, Downward Mobility, and Homelessness in Post-Communist Bucharest. Cultural Antropology, 29 (1), 8-31. DOI: 10.14506/ca29.1.03

Parry, J. \& Bloch, M. (1989). Money and the morality of exchange. Cambridge University Press.

Polan'i, K. (2007). O vere v ekonomicheskii determinizm [On Belief in Economic Determinism]. In «Velikaia transformaciia» Karla Polan'i: proshloe, nastoiashchee, budushchee, (pp. 22-29). Moskva. Retrieved from http://rustem-nureev.ru/wp-content/uploads/2011/01/277.pdf [in Russian].

Polan'i, K. (2007). Ekonomika kak institutsionalno oformlennyi protsess [Economics as an institutionalized process]. In «Velikaia transformaciia» Karla Polan'í: proshloe, nastoiashchee, budushchee, (pp. 4471). Moskva. Retrieved from http://rustem-nureev.ru/wp-content/uploads/2011/01/277.pdf [in Russian].

Polan'i, K. (2007). Semantika ispolzovaniia deneg [The Semantics of Money Uses] In «Velikaia transformaciia» Karla Polan'i: proshloe, nastoiashchee, budushchee, (pp. 125-137). Moskva. Retrieved from http://rustem-nureev.ru/wp-content/uploads/2011/01/277.pdf [in Russian].

Schrader, H. (1999). Ekonomicheskaia antropologiia [Economic Anthropology]. Sankt-Peterburg: Peterburgskoe vostokovedenie [in Russian].

Taussig, M. (2010). The Devil and Commodity Fetishism in South America. The University of North Carolina Press.

Zimmel, G. (1978). Filosofiia deneg [The Philosophy of Money]. Boston [in Russian].

\section{Tetiana Tkhorzhevska}

(Odessa National Polytechnic University, Odesa, Ukraine)

e-mail: tvtchor@gmail.com

ORCID: https://orcid.org/0000-0002-4696-4636

\section{Yulia Bohuslavska}

(Odessa National Polytechnic University, Odesa, Ukraine)

e-mail: boguslav.yulia@gmail.com

ORCID: https://orcid.org/0000-0003-1360-9379

\section{Global Capitalism vs Traditional Culture: Money in the Discourse of Foreign Cultural Anthropology}

The impact of globalization on the existence of local cultures remains the focus of anthropological research. The concept of money is one of the markers of how traditional culture meets global capitalism.

A historiographical review of foreign cultural anthropologists' significant works on this issue is presented in the paper. The way in which scholars interpret the collision of global capitalism and traditional culture is analyzed. The focus is on the place of money, labor, and work motivation in this interpretation.

Many scholars emphasize the destructive nature of the impact of the global on local cultures, based on the tradition founded by Polanyi and developed by Bohannan. According to them, before the emergence of market relations, the need for labor was motivated not by economic but rather by social and moral norms. Global capitalism completely changed the attitude to labor and money, replacing moral norms with utilitarian benefits. Later anthropological studies (J. Parry and M. Bloch, E. Hirschman) are based on the possibility of coexistence of archaic features with modern economic systems in a single cultural matrix. In modern re- 
search works, both approaches coexist including synthetic form as well. In the paper, it is noted that the views of the scholar mostly depend on the level of social ranking at which the object of study is located.

It is mentioned that the range of problems studied by the anthropology of money has changed insignificantly. Thus, for the modern anthropologist, there is a considerable area for studying social transformations and cultural features through the attitude to labor and money.

Keywords: economic anthropology, anthropology of money, traditional culture, work motivation, collision of cultures 